\title{
PENGARUH BRAND IMAGE DAN KUALITAS PELAYANAN TERHADAP KEPUASAN WISATAWAN DALAM MEMILIH TAKSI BLUE BIRD DI BALI
}

\author{
Dewa Ayu Putu Mega Puriani \\ I Wayan Suardana \\ Luh Gede Leli Kusuma Dewi \\ Email : purianimega@gmail.com \\ PS. S1 Industri Perjalanan Wisata \\ Fakultas Pariwisata UNUD
}

\begin{abstract}
In Bali, many types of taxi can be encountered starting from the airport until city and tourist destination, one of them is Blue Bird Taxi. Blue Bird taxi has a brand image and good service quality which can be seen from many awards, some of them are Mark Plus Wow Service Excellence Award 2015 and Indonesian Leading Taxi/Limousine Company. Along with the technology development, giving significant impact to competition among land transportation for instance online based taxi. The technique of determining the respondents is purposive sampling technique with the number of respondents were 170 respondents. Furthermore, in analysing the data, this study using multiple regression analysis techniques.

Results of this study mention that variable dimension dominate on brand image is strength. In partially brand image give positive and significant impact on tourist satisfaction with $t_{\text {count }}$ of 2,465 and significant value of 0,015. And variable dimension dominate on service quality is tangible. Service quality give positive and significant impact on tourist satisfaction with $t_{\text {count }}$ of 9,219 and significant value of 0,000. Simultaneously, it can be concluded that brand image and service quality give positive and significant impact on tourist satisfaction with $F_{\text {count }}$ of 105,731 and significant value of 0,000 .
\end{abstract}

Keywords: Brand Image, Service Quality, Tourist Satisfaction, Blue Bird Taxi.

\section{PENDAHULUAN}

Bali merupakan daerah tujuan wisata yang menghasilkan devisa untuk negara Indonesia. Salah satu sumber devisa di Bali adalah jasa pariwisata yang diperoleh dari kunjungan wisatawan mancanegara maupun domestik. Adanya kunjungan wisatawan yang datang ke Bali membuat dibutuhkannya industri pariwisata yang akan menunjang kepariwisataan. Industri jasa pariwisata tersebut seperti restoran, penginapan, pelayanan perjalanan, transportasi, pengembangan daya tarik wisata, fasilitas rekreasi dan atraksi wisata. Transportasi merupakan sarana penunjang pariwisata yang mampu mengantarkan wisatawan menuju destinasi-destinasi wisata yang ingin yang banyak terdapat di Bali yaitu ojek, bus, dokar, taksi dan lain-lain. Terdapat beberapa perusahaan yang bergerak di moda transportasi taksi seperti koperasi wisata Nusa Dua, koperasi Taksi Jimbaran, Airport Taksi, Ngurah Rai Taksi, Wahana Taksi, serta Blue Bird Taksi. Pengusaha moda transportasi taksi berlomba-lomba untuk memberikan pelayanan yang baik, kemudahan pemesanan, kenyamanan armada agar dapat terwujudnya citra perusahaan yang baik dimata wisatawan. Citra perusahaan yang baik tentu akan terwujud dengan cara memberikan pelayanan yang prima kepada konsumen. Menurut (Lupiyoadi dalam Nisrul Irawati, 2008), perusahaan yang bergerak dalam bidang jasa mencoba untuk memperlihatkan Image-nya 
tambah bagi perusahaan dan juga membuat para konsumen senang dan betah bila perusahaan itu benar memberikan suasana yang nyaman.

Salah satunya adalah perusahaan Blue Bird yang merupakan perusahaan taksi yang sudah memiliki citra merek dan memiliki kualitas pelayanan yang baik dimata pengguna jasanya. Perusahaan Blue Bird sendiri telah mendapatkan beberapa penghargaan seperti penghargaan sebagai Best Brand Award sejak tahun 2011 sampai saat ini perusahaan Blue Bird tetap mendapatkan penghargaan tersebut. Selain itu Blue Bird sendiri terpilih sebagai Indonesia Leading Taxi/Limousine Company dalam Indonesia Travel \& Tourism Awards 2015/2016. Tercatat lebih dari 125 brand industri pariwisata memperebutkan lebih dari 40 kategori ITTA. Brand image merupakan suatu kondisi yang dimiliki oleh produk bila ditinjau dari segi sosial dan psikologi dimana konsumen memiliki perasaan dan gagasan tentang merek yang bersifat krusial terhadap konsumen dalam menentukan pilihannya. Dengan kata lain citra merek sebagai "the sysmbols by which we buy".

Selain itu pada tahun 2015 Blue Bird sendiri mendapatkan penghargaan Mark Plus Wow Service Excellence Award 2015 yang mana penghargaan ini diberikan sebagai bentuk apresiasi terhadap local champion di Bali dalam melakukan pelayanan untuk meningkatkan kepuasan pelanggan, hal tersebut membuktikan bahwa layanan yang diberikan Blue Bird kepada konsumennya memiliki kualitas yang baik yang dapat memberikan kepuasan kepada wisatawan. Kesuksesan serta penghargaan yang didapatkan oleh Blue Bird membuat perusahaan dapat dikatakan unggul dibandingkan dengan perusahaan taksi yang ada di Bali.

Kesuksesan dari Taksi Blue Bird sendiri tidak lepas dari persaingan yang sangat ketat seperti adanya pemesanan taksi secara online. Online taksi merupakan pesaing yang kini menjadi pesaing taksi blue bird. Selain adanya online taksi, adanya sopir taksi nakal yang suka mempermainkan argo dari taksi membuat wisatawan merasa kurang aman, hal tersebut yang membuat berkurangnya kepuasan dari wisatawan dalam menggunakan taksi Blue Bird di Bali.

Rrand imaoo merunakan suatu kendici segi sosial dan psikologi dimana konsumen memiliki perasaan dan gagasan tentang merek yang bersifat krusial terhadap konsumen dalam menentukan pilihannya. Dengan kata lain citra merek sebagai "the sysmbols by which we buy".

Menurut (Kotler dalam Sangadji dan Sopiah, 2013) kualitas merupakan suatu kondisi dinamis yang berhubungan dengan produk, jasa, manusia, proses, dan lingkungan yang memenuhi atau melebihi harapan.

Kepuasan wisatawan adalah sikap wisatawan secara keseluruhan terhadap penyedia layanan, atau reaksi emosional untuk perbedaan antara apa yang wisatawan mengantisipasi dan apa yang mereka terima, mengenai pemenuhan beberapa kebutuhan, tujuan atau keinginan (Hensenark dan Albinson dalam Emmanuel, 2015).

\section{METODE PENELITIAN}

Terdapat beberapa tempat yang dijadikan lokasi penelitian dari taksi Blue bird yaitu di Sanur, Seminyak, Legian, dan Kuta. Lokasi ini dapat mempermudah untuk mendapatkan wisatawan dikarenakan kriteria wisatawan yang digunakan sebagai responden adalah wisatawan yang berkunjung ke Bali untuk berlibur.

Terdapat 3 variabel yaitu Brand Image $\left(X_{1}\right)$, Kualitas Pelayanan $\left(\mathrm{X}_{2}\right)$ sebagai variabel bebas dan Kepuasan Wisatawan sebagai variabel terikat. Adapun indikator dalam variabel brand image yaitu kekuatan (strenght), keunikan (uniqueness), berkenan (favourable). Dalam kualitas pelayanan menggunakan 5 indikator untuk pengukuran yaitu keandalan (reliability), daya tanggap (responsiveness), jaminan (assurance), empati (emphaty) dan benda berwujud (tangibles). Dan untuk pengukuran kepuasan wisatawan menggunakan indikator overal satisfaction yang mana overal satisfaction, yaitu kepuasan secara keseluruhan wisatawan setelah mengkonsumsi merek.

Dalam pengumpulan data digunakan teknik observasi, wawancara, kuesioner, teknik dokumentasi dan studi kepustakaan dengan teknik penentuan sampel menggunakan purposive sampling yang mana wisatawan yang digunakan sebagai responden adalah wisatawan yang datang berlibur ke bali dan pernah menggunakan layanan taksi blue hird denoan iumlah resnonden sehanvak 170 
digunakan adalah dengan menggunakan teknik analisis data regresi berganda.

\section{HASIL}

\section{Karakteristik responden}

Karakteristik wisatawan yang menggunakan taksi Blue Bird di Bali adalah wisatawan yang memiliki rentang usia 21-30 tahun, yang mana jenis kelamin mayoritas adalah perempuan. Pada pendidikan terakhir lebih banyak di dominasi adalah Diploma/S1/S2/S3. Wisatawan yang mendominasi adalah wisatawan yang berasal dari negara Australia dengan status pekerjaan lebih banyak adalah sebagai pegawai swasta, dengan frekuensi kunjungan ke Bali didominasi dengan frekuensi kunjungan sebanyak 2-5 kali yang bertujuan untuk berlibur. Lebih banyak wisatawan yang mendapatkan informasi mengenai Taksi Blue Bird adalah melalui teman. Dalam menggunakan taksi Blue Bird di Bali, frekuensi wisatawan dalam menggunakan selama di Bali didominasi sebanyak 2-5 kali penggunaan.

\section{Hasil Analisis Data}

Hasil uji validitas dengan pengujian statistik yang telah dilakukan kepada seluruh item kuesioner menunjukan bahwa semua item kuesioner dikatakan valid. Hal tersebut berdasarkan dari nilai $\mathrm{r}_{\text {hitung }}$ dari setiap item kuesioner menunjukan nilai yang lebih besar dari $r_{\text {tabel }}(0,150)$.

Untuk uji reliabilitas dilakukan dengan cara menggunakan uji statistik yaitu alfha cronbach. Suatu variabel dianggap reliabel jika nilai alpha diatas 0,6 . Pada pengujian reabilitas yang telah dilakukan, diketahui bahwa setiap indikator variabel mimiliki nilai koefisien alpha yang lebih besar dari 0,6. Hal tersebut menunjukan bahwa indikator pada setiap variabel dapat dikatakan reliabel.

Uji Asumsi Klasik terdiri dari tiga pengujian yaitu uji normalitas, multikolinearitas dan uji heteroskedatisitas. Adapun kriteria untuk uji normalitas yang menyatakan bahwa variabel dapat dikatakan normal yang mana jika Sig $>0,05$. Adapun hasil uji normalitas dilakukan, diketahui bahwa nilai Sig atau Asymp.Sig (2-tailed) pada uji Kolmogovo-Smirnov sebesar 0,774. Hal tersebut menunjukan bahwa angka Sig 0,774 > 0.05. maka danat disimnulkan bahwa data
Regresi yang bebas multikolinieritas ditandai dengan nilai Tolerance lebih besar dari 0,1 dan nilai VIF kurang dari 10 (Ghozali, 2005). Adapun hasil uji multikolinearitas menunjukan bahwa pada nilai tolerance lebih besar dari 0,1 yaitu bernilai 0,571 sedangkan untuk nilai VIF kurang dari 10 yaitu 1,750 . Maka dapat disimpulkan bahwa tidak terjadi multikolinearitas.

Untuk hasil uji heteroskedatisitas menunjukan bahwa variabel brand image memiliki nilai Sig sebesar 0,914 dan kualitas pelayanan sebesar 0,928. Masing-masing variabel memiliki nilai Sig $>0,05$, itu menunjukan bahwa tidak adanya gejala heteroskedastisitas.

Berdasarkan hasil analisis korelasi diketahui bahwa korelasi antar variabel menunjukan arah yang positif yang mana hal tersebut menunjukan apabila brand image dan kualitas pelayanan meningkat maka akan terjadi peningkatan pada kepuasan wisatawan, begitu juga sebaliknya.

Nilai koefisien determinasi dapat diukur oleh nilai $R$-Square. Hasil dari koefisien determinasi persentase pengaruh brand image dan kualitas pelayanan terhadap kepuasan wisatawan dalam memilih taksi blue bird di Bali sebesar 55,9\%, sedangkan sisanya dipengaruhi oleh variabel lain yang terkain dengan kepuasan wisatawan.

Hasil analisis regresi berganda menunjukan bahwa nilai konstanta bernilai positif yaitu sebesar 0,862 dan menunjukan pengaruh positif variabel brand image dan kualitas pelayanan, bila variabel brand image dan kualitas pelayanan meningkat atau berpengaruh maka variabel kepuasan wisatawan akan naik dan berpengaruh. Besarnya perubahan pada variabel kepuasan wisatawan diakibatkan oleh adanya perubahan pada variabel brand image dan kualitas pelayanan.

Pengujian hipotesis menggunakan 2 pengujian yaitu Uji secara parsial (Uji t) dan uji secara simultan (uji F).

a. Uji t (parsial)

Hasil dari uji t (parsial) menunjukan bahwa Nilai $t_{\text {hitung }}$ pada variabel brand image adalah sebesar 2,465 $>\mathrm{t}_{\text {tabel }}$ sebesar 1,654. Dengan nilai signifikasi sebesar $0,015>0,05$, maka dapat disimpulkan bahwa variabel brand image berpengaruh nositif dan sionifikan terhadan kenuasan 
variabel kualitas pelayanan adalah sebesar $9,219>t_{\text {tabel }}$ sebesar 1,654. Dengan nilai signifikasi sebesar $0,000>0,05$, maka dapat disimpulkan bahwa variabel kualitas pelayanan berpengaruh positif dan signifikan terhadap kepuasan wisatawan.

b. Uji F (Simultan)

Adapun hasil menunjukan bahwa nilai $F_{\text {hitung }}$ sebesar 105,731 $>F_{\text {tabel }}$ sebesar 3,05. Sedangkan untuk nilai signifikansi pada penelitian ini sebesar $0,000<$ Sig 0,05. Dari hal tersebut dapat disimpulkan bahwa variabel brand image dan kualitas pelayanan secara simultan berpengaruh positif dan signifikan terhadap kepuasan wisatawan dalam memilih taksi blue bird di Bali.

\section{PEMBAHASAN}

Dari hasil ini mengungkapkan bahwa brand image berpengaruh positif dan signifikan terhadap kepuasan wisatawan. Hasil penelitian ini juga mendukung penelitian dari Chusnul (2014) yang menyatakan bahwa brand image berpengaruh positif dan signifikan terhadap kepuasan pelanggan. Perusahaan yang ingin bertahan harus memiliki nilai lebih dari pada perusahaan lain. Mengelola image perusahaan secara konsisten merupakan komponen strategi pemasaran yang penting akan dapat mempengaruhi nilai yang dirasakan wisatawan dan kepuasan.

Perusahaan Blue bird taksi merupakan perusahaan yang ingin bertahan harus memiliki nilai lebih dari pada perusahaan lain. Mengelola image perusahaan secara konsisten merupakan salah komponen strategi pemasaran yang pentingkan dapat mempengaruhi nilai yang dirasakan wisatawan dan kepuasan. Menurut Kotler (2009) salah satu faktor yang mempengaruhi kepuasan wisatawan adalah (brand image). Brand image yang kuat akan menimbulkan sebuah kepuasan dimata wisatawan. Output dari sebuah kepuasan wisatawan dalam jangka waktu yang panjang adalah akan adanya word of mouth dan intensitas pembelian berulang yang akan menjadikan wisatawan sebagai wisatawan yang loyal.

Dilihat dari karakteristik responden melalui sumber informasi, disana terlihat bahwa sumber informasi yang paling dominan adalah melalui teman sebesar 47,6\%. Hal tersehıt secara tidak lanosuno telah adanva mulut dengan memperkenalkan brand image dari taksi Blue Bird.

Selain itu diketahui bahwa kualitas pelayanan berpengaruh positif dan signifikan terhadap kepuasan wisatawan. Hasil ini juga mendukung penelitian dari Selvy (2013) yang menyatakan bahwa kualitas pelayanan yang bisa diimplementasikan dengan baik merupakan faktor kunci yang memiliki pengaruh terhadap keberhasilan sebuah perusahaan dan dapat menciptakan kepuasan wisatawan. Menurut Crorin dan Taylor kualitas pelayanan mempunyai pengaruh positif terhadap kepuasan wisatawan. Jadi dengan peningkatan kualitas layanan yang diberikan kepada wisatawan maka kepuasan wisatawan akan tercipta.

Kualitas pelayanan yang bisa diimplementasikan dengan baik merupakan faktor kunci yang memiliki pengaruh terhadap keberhasilan sebuah perusahaan dan dapat menciptakan kepuasan wisatawan. Kepuasan yang dirasakan wisatawan dapat mendorong wisatawan tersebut datang dan menggunakan jasa taksi blue bird. Kesadaran pihak blue bird taksi terhadap kualitas pelayanan serta persaingan yang sedang dihadapi, pihak blue bird taksi membuat sebuah layanan online reservasi yang kini dapat mempermudah wisatawan dalam melakukan pemesanan taksi.

Untuk pengaruh brand image dan kualitas pelayanan menunjukan hasil bahwa brand image dan kualitas pelayanan berpengaruh positif dan signifikan terhadap kepuasan wisatawan.Hasil penelitian ini juga mendukung penelitian yang dilakukan oleh Firda (2014) yang menyatakan bahwa brand image dan kualitas pelayanan terdapat pengaruh hubungan yang positif dan signifikan terhadap kepuasan konsumen Diva Karaoke Salemba.

Brand image dan kualitas pelayanan merupakan hal yang sangat penting untuk menciptakan kepuasan wisatawan. Dengan terciptakan kepuasan wisatawan perusahaan harus dapat memperbaiki kekurangan dari kualitas pelayanan dan brand image yang telah diberikan dan selalu berusaha untuk meningkatkannya. Hal tersebut yang membuat brand image dan kualitas pelayanan merupakan faktor untuk membentuk kepuasawan wisatawan. Dalam menciptakan kepuasan wisatawan, perusahaan harus dapat meninokatkan nilai citra merek vano dimiliki 
wisatawan maka semakin tinggi pula kepuasannya.

\section{SIMPULAN}

Berdasarkan hal tersebut maka diperoleh hasil bahwa brand image $\left(\mathrm{X}_{1}\right)$ berpengaruh positif dan signifikan terhadap kepuasan wisatawan (y). Ditemukan bahwa dimensi variabel yang mendominasi pada brand image yaitu kekuatan (strenght).

Berdasarkan hal tersebut maka diperoleh hasil bahwa kualitas pelayanan $\left(\mathrm{X}_{2}\right)$ berpengaruh positif dan signifikan terhadap kepuasan wisatawan (y). Ditemukan bahwa dimensi variabel kualitas pelayanan yang mendominasi adalah benda terwujud (tangible).

Berdasarkan hal tersebut maka diperoleh bahwa brand image dan kualitas pelayanan berpengaruh secara bersamaan terhadap kepuasan wisatawan. Brand image dan kualitas pelayanan berpengaruh positif dan siginifikan terhadap kepuasan wisatawan.

\section{DAFTAR PUSTAKA}

Ariadi, Wahyu. 2010, Analisis Motivasi, Citra Merek, Kepercayaan Merek Dan Gender Terhadap Keputusan Pembelian. Vol 1 No 2

Bahar, Taslim., Tamin, Ofyan., Kusbiantoro, B.S.,Frazila, Russ Bona. 2009. Pengaruh Kualitas Pelayanan Terhadap Kepuasan Dan Loyalitas Penggunaan Moda Angkutan Umum Informal (Studi Kasus Ojek Sepeda Motor). Jurnal Simposium XII FSTPT. Hal. 972-981.

Cronin, J. Joseph, Jr and Steven A. Taylor. 2002. Measuring Service Quality: A Reexamination and Extention. Journal of Marketing. Vol. 56.

Firda. 2014. Pengaruh Kualitas Pelayanan dan Citra Merek terhadap Kepuasan Konsumen dan Dampaknya terhadap Minat Beli Ulang pada PT. Diva Karaoke. Jurnal Bisnis Manajemen. Vol.4 No1.

Ghozali, Imam. 2005. Aplikasi Analisis Multivariate Dengan Program Spss. Semarang : Universitas Diponegoro.

Kotler, Philip dan Kevin Lane Keller. 2008. Manajemen Pemasaran. Jakarta: Erlangga.

Khotimah, Chusnul. 2016. Pengaruh Relationshin Marketino dan Rrand
Loyalitas Pelanggan (Survei terhadap pelanggan Indihome PT. Telkom, Tbk.STO. Vol 36 No. 1.

Normasari, Selvy. 2013. "Pengaruh Kualitas

Pelayanan Terhadap Kepuasan

Pelanggan, Citra Perusahaan Dan

Loyalitas Pelanggan (Survei pada tamu pelanggan yang menginap di hotel Pelangi Malang)". Jurnal Administrasi Bisnis. Vol.6 No.2

Riduwan. 2013. Skala Pengukuran VaiabelVariabel Penelitian. Bandung: Alfabeta.

Roostika, Ratna. 2012. "Analisis Pengaruh Bauran Pemasaran Produk Cindera Mata terhadap Kepuasan Wisatawan Domestik di Yogyakarta". Jurnal Manajemen dan Akuntansi. Vol 1 No. 3

Sangadji \& Sopiah. 2013. Prilaku Konsumen: Pendekatan Praktis Disertai: Himpunan Jurnal Penelitian. Yogyakarta: Andi.

Subagio, Hartono dan Robin. 2012. Pengaruh Perceived Service Quality,Perceived Value, Satisfaction dan Image Terhadap Customer Loyalty (Studi Kasus Garuda Indonesia). Vol7. No 1. 